\title{
ANALISIS POTENSI DAN PENGEMBANGAN AGRIBISNIS SAYURAN DI KABUPATEN KARANGANYAR
}

\section{Analysis of The Potential And Development of Vegetable Agribusiness in Karanganyar District}

\author{
Ratih Dwi Kartikasari*, Suswadi, Sutarno \\ Program Studi Agribisnis, Fakultas Pertanian Universitas Tunas Pembangunan Surakarta \\ Jl. Balekambang lor no.1 Manahan Surakarta \\ *corresponden author: ratihkartika14@gmail.com
}

\begin{abstract}
Karanganyar Regency has a strategic role in economic development in Indonesia, especially in the agricultural sector. This study aims to determine the potential for agribusiness development, especially vegetable commodities in Karanganyar Regency by using the Location Quotient (LQ) method. Mapping with the LQ method will produce commodities that are classified as basic or non-basic commodities that can contribute to the welfare of farmers, especially increasing income. The data used are secondary data about vegetable production in Karanganyar Regency in 2019 and primary data from interviews with farmers. The results showed that there were 6 vegetable commodities cultivated in 17 districts, namely onions, large chilies, potatoes, cabbage, Chinese cabbage, tomatoes and garlic. The highest $L Q$ value is large chili, while the second to lowest is onions, potatoes, tomatoes and Chinese cabbage. The white yawl commodity has not become a base commodity because the LQ value is $<1$ in all districts in Karanganyar Regency.
\end{abstract}

Keywords : Base Comodities, Location Quotient, Vegetables

\section{ABSTRAK}

Kabupaten Karanganyar memiliki peran yang strategis dalam pembanguan perekonomian di Indonesia, khususnya pada sektor pertanian. Penelitian ini bertujuan untuk mengetahui potensi pengembangan agribisnis khususnya komoditas sayuran di Kabupaten Karanganyar dengan menggunakan metode Location Quotient (LQ). Pemetaan dengan metode LQ akan menghasilkan komoditas yang tergolong dalam komoditas basis ataupun komoditas non basis yang dapat berkontribusi pada kesejahteraan petani khususnya peningkatan pendapatan. Data yang digunakan adalah data sekunder tentang produksi sayuran di Kabupaten Karanganyar pada tahun 2019 serta data primer hasil wawancara dengan petani. Hasil penelitian menunjukkan bahwa terdapat 6 komoditas sayuran yang dibudidayakan di 17 kecamatan yaitu bawang merah, cabai besar, kentang, kubis, petsai, tomat dan bawang putih. Nilai LQ tertinggi adalah cabai besar, sementara urutan kedua sampai dengan terendah adalah bawang merah, kentang, tomat dan petsai. Komoditas bawag putih belum menjadi komoditas basis dikarenakan nilai LQ <1 pada seluruh kecamatan di Kabupaten Karanganyar.

Kata Kunci : Komoditas Basis, Location Quotient,Sayuran

\section{PENDAHULUAN}

Sektor pertanian menjadi sektor pendukung pembangunan perekonomian nasional di Indonesia karena terbukti banyak menyentuh lapisan masyarakt pedesaan dalam penyerapan tenaga kerja (Arsyad, 2009).
Wilayah di negara Indonesia memiliki karakteristik dan potensi yang berbeda satu dengan yang lain. Salah satu wilayah dengan potensi sumberdaya alam cukup berlimpah adalah Kabupaten Karanganyar Provinsi Jawa Tengah. Faktor geografis suatu wilayah disertai dengan adanya tingkat pertumbuhan ekonomi menjadi faktor utama keberhasilan pembangunan ekonomi pada wilayah tersebut (Spolaore dan Wacziarg, 2013). 
ISSN : 2721-074X (Online) - 2301-6698 (Print)

Available on : http://ejournal.utp.ac.id/index.php/AFP/index

This is Under CC BY SA Licence

Tabel 1. Distribusi Persentase PDRB ADHB Menurut 5 Lapangan Usaha teratas di Kabupaten Karanganyar Tahun 2015-2019

\begin{tabular}{lccccc}
\hline \multicolumn{1}{c}{ Lapangan Usaha } & \multicolumn{5}{c}{ Tahun } \\
\cline { 2 - 6 } & 2015 & 2016 & 2017 & 2018 & 2019 \\
\hline Industri Pengolahan & 45,21 & 45,57 & 45,68 & 45,78 & 46,01 \\
Pertanian, Kehutanan, dan Perikanan & 14,89 & 14,41 & 13,73 & 13,45 & 12,90 \\
Perdagangan besar dan eceran; reparasi mobil dan sepeda motor & 11,10 & 11,13 & 11,23 & 11,22 & 11,33 \\
Konstruksi & 6,37 & 6,43 & 6,65 & 6,97 & 7,19 \\
Jasa pendidikan & 4,27 & 4,32 & 4,45 & 4,46 & 4,50 \\
\hline Sumber: BPS 2020 & & & & &
\end{tabular}

Menurut Muta'ali (2015) pertumbuhan ekonomi suatu daerah erat dipengaruhi oleh permintaan terhadap barang dan jasa dari luar daerah atau besarnya peningkatan ekspor dari wilayah tersebut. Semakin banyak sektor basis dalam suatu wilayah akan meningkatkan pendapatan ke wilayah tersebut. Sehingga dampak jangka panjang yang dirasakan masyarakat adalah berkurangnya kemiskinan (Miranti \& Cassells, 2014).

Pertanian di Kabupaten Karanganyar potensial untuk terus dikembangkan karena didukung oleh kondisi agroekosistem yang sesuai. Berdasarkan tabel 1 lapangan usaha pertanian, kehutanan dan perikanan dari tahun 2015 sampai 2019 selalu menempati urutan kedua setelah sektor industri pengolahan. Hal ini menunjukkan sektor pertanian, kehutanan dan perikanan memiliki kontribusi dan potensi untuk mendukung PDRB daerah dan dapat dikembangkan di masa mendatang.

Kabupaten Karanganyar berlokasi di daerah dataran tinggi yang sangat mendukung dalam pengembangan pertanian, salah satu komoditas unggulannya yaitu jenis hortikultura seperti sayuran. Dalam penelitian Kipdiyah, Hubeis \& Suharjo (2013) menyatakan bahwa beberapa keuntungan dalam melakukan budiday sayuran adalah dapat memenuhi gizi masyarakat, meningkatkan pendapatan dan kesejahteraan petani serta dapat memenuhi permintaan pasar nasional maupun internasional yang semakin tinggi. Tujuan dari penelitian ini adalah untuk mengidentifikasi dan menganalisis potensi sektor pertanian khususnya pada komoditas sayuran di Kabupaten Karanganyar dengan metode Location Quotient (LQ) sehingga dapat ditentukan strategi pengembangan sektor pertanian agribisnis di Kabupaten Karanganyar.

\section{METODE PENELITIAN}

Lokasi penelitian berada di Kabupaten Karanganyar dengan beberapa pertimbangan, diantaranya adalah 1) Kontribusi PDRB lapangan usaha pertanian di Kabupaten Karanganyar tergolong tinggi yaitu menempati urutan kedua dari 17 lapangan usaha;2)produksi sayuran di Kabupaten Karanganyar terus meningkat dari tahun 2018 sampai 2019 dari beberapa kabupaten lain di provinsi Jawa Tengah.

Sumber data yang digunakan adalah data sekunder dari berbagai sumber seperti BPS Jawa Tengah, BPS Kabupaten Karanganyar dan sumber lain. Sedangkan data primer yang digunakna meliputi data yang diperoleh dari hasil wawancara dengan petani sayuran di Kabupaten Karanganyar guna mendukung data sekunder yang diambil. Penentuan komoditas sayuran unggulan di Kabupaten Karanganyar didapatkan dengan cara menelaah dokumen produksi komoditas asyuran yang dihasilkan di masing-masing kecamatan di Kabupaten Karanganyar dan selanjutnya dianalisis dengan metode Location Quotient (LQ) dengan alat analisis Ms. Excel 2010. Rumus yang digunakan adalah :

$$
L Q=\frac{v i / v t}{V i / V t}
$$

Dimana

LQ : Index Location Quotient

vi : produksi sayuran i pada tingkat kecamatan 


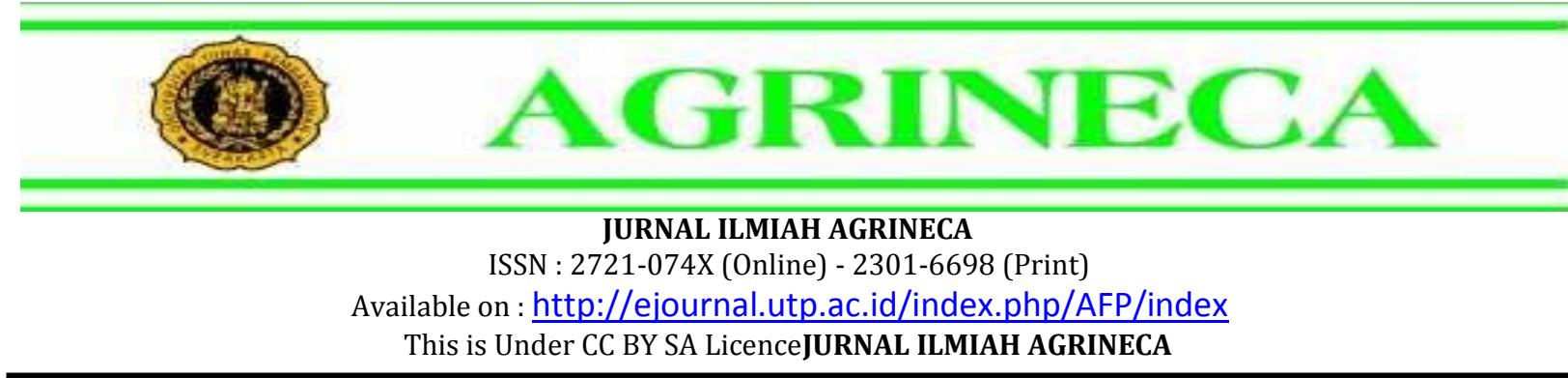

vt : produksi sayuran total pada tingkat kecamatan

Vi : produksi sayuran i pada tingkat kabupaten

$\mathrm{Vt}$ : produksi sayuran total pada tingkat kabupaten

(Suyana, 2010).

Dengan kriteria sebagai berikut :

Bila LQ >1, maka komoditas tersebut merupakan komoditas basis.

Bila LQ $<1$, maka komoditas tersebut adalah komoditas non basis.

Bila $\mathrm{LQ}=1$, maka komoditas tersebut hanya dapat untuk memenuhi kebutuhan daerahnya saja (swasembada/self-sufficiency)

(Budiharsono, 2001).

\section{HASIL DAN PEMBAHASAN}

Hasil analisis menunjukkan setiap wilayah kecamatan di Kabupaten Karanganyar memiliki nilai LQ yang berbeda satu dengan yang lain. Suatu sektor atau komoditas dikatakan basis apabila memperoleh nilai LQ>1 dan menyiratkan bahwa sektor atau komoditas di wilayah tersebut dan berpotensi untuk dikembangkan sebagai pendorong ekonomi lokal. Tetapi bila nilai $\mathrm{LQ}<1$ menunjukkan bukan sektor dominan dan kurang potensial untuk dikembangkan sebagai pendorong ekonomi lokal.Sementara komoditas dengan nilai $\mathrm{LQ}=1$ menunjukkan komoditas secara produksi sudah cukup baik namun hanya cukup untuk memenuhi kebutuhan lokal Dalam kajian ini, hasil analisis LQ dihitung berdasarkan jumlah produksi komoditas sayuran di 17 kecamatan di Kabupaten Karanganyar.

Berdasarkan tabel 2 diketahui bahwa petani sayuran di Kecamatan Jatipuro sebagian besar hanya memproduksi bawang merah dan cabai besar dengan masing-masing produksi 222,2 ton dan 8 ton pada tahun 2019. Dari hasil analisis diketahui komoditas sayuran basis di Kecamatan Jatipuro adalah bawang merah dengan nilai LQ yang cukup tinggi yaitu 6,93. Sementara di Kecamatan Jatiyoso produksi sayuran tertinggi adalah kubis dengan jumlah
453,2 ton. Komoditas basis dengan nilai LQ>1 yaitu komoditas cabai besar dan kubis. Sementara komoditas non basis yaitu petsai dan bawang putih. Nilai produksi cabai besar 163,2 ton lebih rendah dibandingkan dengan produksi petsai yaitu 191,3 ton akan tetapi nilai LQ pada kedua komoditas tersebut tidak linear. Hal ini menunjukkan nilai LQ yang tinggi bukan mencerminkan areal panen yang luas akan tetapi merupakan cerminan nilai relatif terhadap share komoditas dalam wilayah yang lebih luas (Hendayana, 2013).

Komoditas basis pada Kecamatan Jumapolo adalah sayuran cabai besar dengan nilai LQ 7,63 sementara sayuran tomat menjadi komoditas non basis dengan nilai LQ 0,15. Pada kecamatan Jumantono, hanya terdapat sayuran cabai besar dengan jumlah produksi 182,5 ton. Sementara dari beberapa sayuran yang di produksi di Kecamatan Matesih hanya satu yang menjadi komoditas basis yaitu bawang merah dengan nilai LQ 6,32. Sementara sayuran lain seperti cabai besar, kubis, petsai dan tomat menjadi komoditas non basis di wilayah Matesih. Kecamatan di Kabupaten Karanganyar yang memiliki komoditas basis paling banyak yaitu kecamatan Tawangmangu. Komoditas basis pada kecamatan Tawangmangu adalah kentang, kubis dan petsaidengan masing-masing nilai LQ adalah 2,13; 1,20; dam 1,50. Komoditas sayuran basis pada kecamatan Ngargoyoso dan Karangpandan adalah cabai besar dan tomat. Sementara pada 8 kecamtan lain yaitu Karanganyar, Jaten, colomadu, Gondangrejo, Kebakkramat, Mojogedang, Kerjo dan Jenawi komoditas cabai besar masih menjadi komoditas basis dengan nilai LQ>1. Sementara pada kecamatan Kebakkramat dan Mojogedang tidak hanya cabai besar yang menjadi komoditas basis, melainkan terdapat komoditas bawang merah yang juga memiliki nilai LQ>1. Komoditas kubis selain menjadi komoditas basis di Kecamatan Jatiyoso dan Tawangmangu juga menjadi unggulan di Kecamatan Jenawi.

Dari beberapa komoditas basis di 17 kecamatan di Kabupaten Karanganyar, nilai LQ tertinggi adalah 7,94 yang merupakan komoditas cabai besar di kecamatan Jumantono, 
ISSN : 2721-074X (Online) - 2301-6698 (Print)

Available on : http://ejournal.utp.ac.id/index.php/AFP/index

This is Under CC BY SA Licence

Karanganyar, Jaten, Colomadu dan Gonangrejo.

Sementara komoditas basis dengan nilai LQ terendah yaitu 1,17 yang juga merujuk pada komoditas cabai besar di kecamatan Jenawi.

Kecamatan Tasikmadu merupakan

kecamatan yang sama sekali tidak memiliki

Tabel 2. Produksi Tanaman Sayuran Menurut Kecamatan dan Jenis Tahun 2019 Tanaman di Kabupaten

Karanganyar (ton)

\begin{tabular}{|c|c|c|c|c|c|c|c|c|c|}
\hline No & Kecamatan & $\begin{array}{l}\text { Bawang } \\
\text { Merah }\end{array}$ & $\begin{array}{l}\text { Cabai } \\
\text { Besar }\end{array}$ & Kentang & Kubis & Petsai & Tomat & $\begin{array}{c}\text { Bawang } \\
\text { Putih }\end{array}$ & Jumlah \\
\hline 1 & Jatipuro & 222,2 & 8 & 0 & 0 & 0 & 0 & 0 & 230,2 \\
\hline 2 & Jatiyoso & 0 & 163,2 & 0 & 453,2 & 191,3 & 0 & 139,2 & 946,9 \\
\hline 3 & Jumapo lo & 0 & 654,6 & 0 & 0 & 0 & 26,8 & 0 & 681,4 \\
\hline 4 & Jumantono & 0 & 182,5 & 0 & 0 & 0 & 0 & 0 & 182,5 \\
\hline 5 & Matesih & 2290 & 39,7 & 0 & 104,2 & 30,1 & 139,3 & 0 & 2603,3 \\
\hline 6 & Tawangmangu & 265,9 & 85,5 & 300 & 3211 & 3992,5 & 90,5 & 2181,2 & 10126,6 \\
\hline 7 & Ngargo-yoso & 0 & 688,3 & 0 & 909,2 & 798,8 & 1214 & 230,8 & 3841,1 \\
\hline 8 & Karangpandan & 0 & 137,2 & 0 & 0 & 47 & 203,3 & 0 & 387,5 \\
\hline 9 & Karanganyar & 0 & 88,2 & 0 & 0 & 0 & 0 & 0 & 88,2 \\
\hline 10 & Tasikmadu & 0 & 0 & 0 & 0 & 0 & 0 & 0 & 0 \\
\hline 11 & Jaten & 0 & 20 & 0 & 0 & 0 & 0 & 0 & 20 \\
\hline 12 & Colomadu & 0 & 0,2 & 0 & 0 & 0 & 0 & 0 & 0,2 \\
\hline 13 & Gondangrejo & 0 & 0,3 & 0 & 0 & 0 & 0 & 0 & 0,3 \\
\hline 14 & Kebakkramat & 34,9 & 38,7 & 0 & 0 & 0 & 0 & 0 & 73,6 \\
\hline 15 & Mojogedang & 50,8 & 81,1 & 0 & 0 & 0 & 0 & 0 & 131,9 \\
\hline 16 & Kerjo & 14,1 & 213,9 & 0 & 0 & 21,8 & 6 & 0 & 255,8 \\
\hline 17 & Jenawi & 248,1 & 426,2 & 12,5 & 1237,3 & 413,4 & 332,2 & 211 & 2880,7 \\
\hline $\mathrm{K}$ & $\begin{array}{l}\text { Kabupaten } \\
\text { aranganyar }\end{array}$ & 3126 & 2827,6 & 312,5 & 5914,9 & 5494,9 & 2012,1 & 2762,2 & 22450,2 \\
\hline
\end{tabular}

Sumber : Data sekunder diolah, 2021

mata pencaharian di sektor industri. Berbeda dengan kecamatan Tawangmangu yang memiliki komoditas sayuran basis paling banyak diantara seluruh kecamatan di Kabupaten Karanganyar. Kecamatan Tawangmangu yang berada pada areal pegunungan yang subur dan kondisi lingkungan yang mendukung sehingga sesuai untuk kegiatan pertanian.

Berdasarkan hasil analisis LQ diatas ada 6 jenis sayuran yang layak untuk dikembangkan di Kabupaten Karanganyar yaitu bawang merah, cabai besar, kentang, kubis, petsai, dan tomat. Cabai besar menjadi komoditas basis yang paling banyak berkembang di Kabupaten Karanganyar, yaitu mencapai 15 dari 17 komoditas basis dikarenakan produksi sayuran yang tergolong rendah bahkan sulit untuk ditemui. Hal ini lantaran kondisi Kecamatan Tasikmadu yang dekat dengan perkotaan dan sebagian besar penduduknya mempunyai 
JURNAL ILMIAH AGRINECA

ISSN : 2721-074X (Online) - 2301-6698 (Print)

Available on : http://ejournal.utp.ac.id/index.php/AFP/index

This is Under CC BY SA LicenceJURNAL ILMIAH AGRINECA

\begin{tabular}{clrrrrrrr}
\hline \multicolumn{2}{c}{ Tabel 3. Hasil Analisis LQ Komoditas Sayuran di Kabupaten Karanganyar } \\
\hline No & Kecamatan & $\begin{array}{c}\text { LQ } \\
\text { Bawang } \\
\text { Merah }\end{array}$ & $\begin{array}{c}\text { LQ Cabai } \\
\text { Besar }\end{array}$ & $\begin{array}{c}\text { LQ } \\
\text { Kentang }\end{array}$ & LQ Kubis & LQ Petsai & $\begin{array}{c}\text { LQ } \\
\text { Tomat }\end{array}$ & $\begin{array}{c}\text { LQ } \\
\text { Bawang } \\
\text { Putih }\end{array}$ \\
\hline 1 & Jatipuro & 6,93 & 0,28 & 0 & 0 & 0 & 0 & 0 \\
2 & Jatiyoso & 0 & 1,37 & 0 & 1,82 & 0,77 & 0 & 0,56 \\
3 & Jumapolo & 0 & 7,63 & 0 & 0 & 0 & 0,15 & 0 \\
4 & Jumantono & 0 & 7,94 & 0 & 0 & 0 & 0 & 0 \\
5 & Matesih & 6,32 & 0,12 & 0 & 0,15 & 0,04 & 0,2 & 0 \\
6 & Tawangmangu & 0,19 & 0,07 & 2,13 & 1,2 & 1,5 & 0,03 & 0,82 \\
7 & Ngargoyoso & 0 & 1,42 & 0 & 0,9 & 0,79 & 1,2 & 0,23 \\
8 & Karangpandan & 0 & 2,81 & 0 & 0 & 0,46 & 1,99 & 0 \\
9 & Karanganyar & 0 & 7,94 & 0 & 0 & 0 & 0 & 0 \\
10 & Tasikmadu & 0 & 0 & 0 & 0 & 0 & 0 & 0 \\
11 & Jaten & 0 & 7,94 & 0 & 0 & 0 & 0 & 0 \\
12 & Colomadu & 0 & 7,94 & 0 & 0 & 0 & 0 & 0 \\
13 & Gondangrejo & 0 & 7,94 & 0 & 0 & 0 & 0 & 0 \\
14 & Kebakkramat & 3,41 & 4,17 & 0 & 0 & 0 & 0 & 0 \\
15 & Mojogedang & 2,77 & 4,88 & 0 & 0 & 0 & 0 & 0 \\
16 & Kerjo & 0,4 & 6,64 & 0 & 0 & 0,32 & 0,09 & 0 \\
17 & Jenawi & 0,62 & 1,17 & 0,31 & 1,63 & 0,54 & 0,44 & 0,28 \\
\hline
\end{tabular}

Sumber : Data sekunder diolah, 2021

Selain cabai, pengembangan bawang merah juga mempunyai prospek karena 4 kecamatan di Kabupaten Karanganyar memiliki nilai LQ>1. Pengembangan bawang merah ditujukan untuk peningkatan kesejahteraan petani, perluasan kesempatan kerja, pengembangan agribisnis serta sebagai upaya pengurangan impor dan memacu laju pertumbuhan ekspor.

Upaya pengembagan agribisnis komoditas sayuran basis di Kabupaten Karanganyar ditujukan untuk penigkatan pendapatan petani serta pendapatan daerah. Selain itu juga akan merangsang daya konsumsi dan berdampak pada peningkatan permintaan komoditas non basis.Dari tabel 3 . diketahui nilai LQ tertinggi untuk komoditas bawang merah dengan nilai 6,93 berada di Kecamatan Jatipuro; komoditas cabai besar berada di Kecamatan Jumantono, Karanganyar, Jaten, Colomadu, dan Gondangrejo dengan nilai 7,94; komoditas kentang hanya menjadi komoditas basis di satu kecamatan yaitu kecamtan Tawangmangu dengan nilai 2,13; komoditas kubis berada di kecamatan Jatiyoso dengan nilai 1,82; komoditas petsai sama dengan kentang yang hanya menjadi komoditas basis di Kecamatan Tawangmangu dengan nilai 1,5; sementara untuk komoditas tomat nilai LQ tertinggi berada di kecamatan Karangpandan dengan nilai 1,99. Hal ini menunjukkan setiap wilayah di Kabupaten Karanganyar memiliki potensinya masing-masing yang perlu dikembangkan sesuai dengan sumberdaya alam yang mendukung di setiap wilayah.

\section{KESIMPULAN DAN SARAN}

Berdasarkan hasil analisis kesimpulan yang dapat dirumuskan adalah tujuh jenis sayuran yang paling banyak menghasilkan nilai LQ>1 adalah sayuran cabai besar yang tersebar di 13 kecamatan di Kabupaten Karanganyar. 


\section{ISSN : 2721-074X (Online) - 2301-6698 (Print) \\ Available on : http://ejournal.utp.ac.id/index.php/AFP/index}

This is Under CC BY SA Licence

Kelompok komoditas yang menghasilkan nilai LQ terbesar adalah cabai besar di urutan pertama dan bawang merah di urutan kedua. Pengembangan komoditas sayuran basis tersebu layak mendapatkan perhatian dari stakeholder yang terlibat di dalamnya sehingga dapat memberikan dampak positif kepada masyarakat maupun Kabupaten Karanganyar. Dengan pengembangan yang sesuai maka angka impor untuk beberapa jenis sayuran seperti cabai dan bawang merah dapat ditekan bahkan ditingkatkan laju pertumbuhan ekspornya. Upaya perbaikan proses budidaya serta dukungan pemerintah yang sejalan dapat meningkatkan kualitas dan kuantitas produk sehingga petani lebih sejahtera dan peningkatan pendapatan daerah akan semakin meningkat.

\section{DAFTAR PUSTAKA}

Anwarudin, M.J., Sayekti A.L., Mahendra, A. \& Hilman, Y. 2013. Dinamika Produksi dan Volatilitas Harga Cabai : Antisipasi Strategi dan Kebijakan Pengembangan. Pengembangan Inovasi Pertanian. Vol.8 No.1 pp : 33-42.

Arsyad, L. 2009. Pengantar Perencanaan dan Pembangunan Ekonomi Daerah. Yogyakarta : BPFE UGM.

Budiharsono, S. 2001. Teknik Analisis Pembangunan Wilayah Pesisir dan Lautan. Jakarta: PT Pradnya Paramita.

Yuendini, E.P.,Rachmi, I.N., Puspitasari, N.N.A., Harini, R., \& Alfana, M. A.F. 2019. Analisis Potensi Ekonomi Sektor Pertanian dan Sektor Pariwisata di Provinsi Bali Menggunakan Teknik Analisis Regional. Jurnal Geografi. No. 16 Vol. 2. Pp : 128-136.
Harinta, Y.W., Basuki, J.S. \& Sukaryani, S. 2018 Pemetaan dan Pengembangan Agribisnis Komoditas Unggulan Sayuran di Kabupaten Karanganyar. Jurnal Agriekonomika. Vol. 7. No.1 pp : 37-45.

Hendayana, R. 2013. Analysis Of The Potential And Development Of Vegetable Agribusiness In Karanganyar District. Informatika Pertanian. Vol. 12. Pp : 1-21.

Kipdiyah, S., Hubeis, M., \& Suharjo, B. 2013 Strategi Rantai Pasok Sayuran Organik Berbasis Petani di Kecamatan Pangalengan, Kabupaten Bandung. Manajemen IKM. Vol.8 No.2. pp: 99-114.

Miranti, R.A.D. and R. Cassells. 2014. Revisiting the Impact of Consumption Growth and Inequality on Poverty in Indonesia during Decentralisation. Bulletin of Indonesian Economic Studies (BIES). Vol 50 No. 3.pp: 461-482.

Muta'ali, L. 2015. Teknik Analisis Regional Untuk Perencanaan Wilayah Tata Ruang dan Lingkungan. Yogyakarta: BPFG.

Spolaore, E and R. Wacziarg.2013.How Deep Are The Roots OfEconomi Development. Journal Of Economic LiteratureVol.51. No.2.pp:325369.

Suyana, U. 2010.Buku Ajar Ekonomi Regional. Denpasar: Fakultas Ekonomi Universitas Udayana. 